\title{
Effect of Feeding Protein Supplements of Differing Degradability on Omasal Flow of Microbial and Undegraded Protein ${ }^{1}$
}

\author{
S. M. Reynal*, G. A. Broderick,† S. Ahvenjärvi,‡ and P. Huhtanen \\ *Department of Dairy Science, University of Wisconsin \\ †Agricultural Research Service, USDA \\ US Dairy Forage Research Center \\ 1925 Linden Drive West, Madison, WI 53706 \\ $\ddagger$ Agricultural Research Center of Finland (MTT) \\ Animal Production Research, FIN-31600 Jokioinen, Finland
}

\begin{abstract}
Ten ruminally cannulated lactating Holstein cows that were part of a larger trial studying the effects of feeding different proteins on milk production were used in a replicated $5 \times 5$ Latin square to quantify flows of microbial and rumen-undegradable protein (RUP) in omasal digesta. Cows were fed total mixed rations containing (dry matter basis) $44 \%$ corn silage, $22 \%$ alfalfa silage, $2 \%$ urea, and $31 \%$ concentrate. The basal diet contained $31 \%$ high-moisture corn; equal $\mathrm{N}$ from one of four protein supplements was added to the other diets at the expense of corn: 9\% solvent soybean meal (SSBM), $10 \%$ expeller soybean meal (ESBM), 5.5\% blood meal (BM), and 7\% corn gluten meal (CGM). Omasal sampling was used to quantify total AA N (TAAN) and nonammonia N (NAN) flows from the rumen. Estimates of RUP were made from differences between total and microbial $\mathrm{N}$ flows, including a correction for RUP in the basal diet. Modifying a spectrophotometric assay improved total purine recovery from isolated bacteria and omasal samples and gave estimates of microbial TAAN and NAN flows that were similar to a standard HPLC method. Linear programming, based on AA patterns of the diet and isolated omasal bacteria and ruminal protozoa, appeared to overestimate microbial TAAN and NAN flows compared to the purine assays. Yields of microbial TAAN and NAN determined using any method was not affected by diet and averaged 32 to $35 \mathrm{~g}$ NAN per kilogram of organic matter truly digested in the rumen. On average, National Research Council (NRC) equations underpredicted microbial N flows by $152 \mathrm{~g} / \mathrm{d}$ (vs. HPLC), $168 \mathrm{~g} / \mathrm{d}$ (vs. spectrophotometry), and $244 \mathrm{~g} / \mathrm{d}$ (vs. linear program-
\end{abstract}

\footnotetext{
Received June 14, 2002.

Accepted October 8, 2002.

Corresponding author: G. A. Broderick; e-mail: glenb@dfrc. wisc.edu.

${ }^{1}$ Mention of any trademark or proprietary product in this paper does not constitute a guarantee or warranty of the product by the USDA or the Agricultural Research Service and does not imply its approval to the exclusion of other products that also may be suitable.
}

ming). Estimates of RUP (means from the HPLC and spectrophotometric methods) were: SSBM, 27\%, ESBM, $45 \%$, BM, $60 \%$, and CGM, 73\%. Except for CGM, RUP values averaged about 20 percentage units lower than those reported by the NRC.

(Key words: dairy cows, degradation, protein, purines)

Abbreviation key: ADIN = acid detergent insoluble N, $\mathbf{B M}=$ blood meal, $\mathbf{C G M}=$ corn gluten meal, $\mathbf{E S B M}=$ expeller soybean meal, FP = fluid phase, $\mathbf{H M S C}=$ rolled high-moisture shelled corn, $\mathbf{L P}=$ large particle phase, NDIN = neutral detergent insoluble N, OMTDR $=$ organic matter truly digested in the rumen, $\mathbf{O T D}=$ omasal true digesta, $\mathbf{S P}=$ small particle phase, $\mathbf{S S B M}=$ solvent soybean meal, TAAN = total amino acid N.

\section{INTRODUCTION}

We needed to determine the contribution of microbial protein to total protein flow from the rumen in an in vivo study designed to quantify ruminal escape of four protein concentrates (Reynal and Broderick, 2003). Values of RUP were to be computed by subtracting microbial protein from total omasal protein flow. Therefore, to have reliable estimates of RUP, it was necessary to measure microbial protein with considerable accuracy. Total purines are used widely as internal microbial markers (Broderick and Merchen, 1992). The total purine procedure of Zinn and Owens (1986), with modifications (Ushida et al., 1985; Aharoni and Tagari, 1991), has been used extensively to estimate microbial protein flow from the rumen. However, recent publications (Obispo and Dehority, 1999; Makkar and Becker, 1999; Mass et al., 1999) reported low recoveries of total purines using the method of Zinn and Owens (1986). Makkar and Becker (1999) found that a modification of the Zinn and Owens (1986) technique and an HPLC procedure both yielded improved purine recoveries.

Microbial protein is derived from a complex mixture of organisms flowing out of the rumen, including bacteria associated with the fluid and particle phases, plus proto- 
zoa. Internal and external microbial markers have been found to have different marker:protein ratios in the bacteria associated with the different ruminal phases (Craig et al., 1987; Firkins et al., 1987) and between the bacteria and protozoa (Hristov and Broderick, 1996). Thus, no single ratio of marker:protein would be appropriate to obtain an absolute determination of total microbial protein synthesized in the rumen. Shabi et al. (2000) used linear programming based on the AA composition patterns of isolated bacteria and protozoa, plus dietary and endogenous protein, to estimate the relative contributions from these four sources to total AA flow from the rumen. A mathematical approach of this type may not be influenced by factors altering purine:protein ratio, such as microbial growth rate (Broderick and Merchen, 1992), and may be more reliable for estimating AA contributions from each fraction.

The objectives of this experiment were 1) to compare use of a modified total purine assay with a standard HPLC purine method and linear programming for quantifying microbial protein in omasal digesta and 2) to determine the proportions of RUP in four different protein concentrates.

\section{MATERIALS AND METHODS}

\section{Experimental Procedure}

Ten ruminally cannulated Holstein cows that were part of a larger trial studying the effects of feeding different protein concentrates on milk production and protein degradation (Reynal and Broderick, 2003) were assigned to a replicated $5 \times 5$ Latin square. Cows were fed TMR containing (DM basis) $43.5 \%$ rolled corn silage, $22 \%$ alfalfa silage, $2 \%$ urea, $1.5 \%$ minerals, and $31 \%$ concentrate [protein supplement plus rolled high-moisture shelled corn (HMSC)]. Proteins were added in the concentrate at the expense of HMSC to provide $4.8 \%$ dietary CP (DM basis): $\operatorname{diet~A~(basal),~(31\% ~HMSC);~} \operatorname{diet} \mathrm{B}$ [22\% HMSC, 9\% solvent soybean meal (SSBM)]; diet C [21\% HMSC, 10\% expeller soybean meal (ESBM; SoyPlus, West Central, Ralston, IA)], diet D [25.5\% HMSC, 5.5\% ring-dried blood meal (BM)]; and diet E [24\% HMSC, $7 \%$ corn gluten meal (CGM)]. Care and handling of the experimental animals, including ruminal cannulation, was conducted as outlined in the guidelines of the University of Wisconsin institutional animal care and use committee. Other details of the feeding trial are described in the companion report (Reynal and Broderick, 2003).

Indigestible NDF (Huhtanen et al., 1994), Co-EDTA (Uden et al., 1980), and $\mathrm{YbCl}_{3}$ (Siddons et al., 1985) were used as markers to assess digesta flows at the omasal canal in the cannulated cows. The $\mathrm{YbCl}_{3}$ was prepared by adding $230 \mathrm{~g}$ of $\mathrm{Yb}_{2} \mathrm{O}_{3}$ to $200 \mathrm{ml}$ distilled water plus
$320 \mathrm{ml}$ concentrated $\mathrm{HCl}$, heating and stirring until the solution was clear, then diluting to $5 \mathrm{~L}$ with distilled water. The Co-EDTA and $\mathrm{YbCl}_{3}$ were dissolved in distilled water and infused into the rumen at a constant rate of, depending on the period, 1.1 or $2.9 \mathrm{~g}$ Co per day and 2.6 or $4.7 \mathrm{~g} \mathrm{Yb}$ per day. The higher infusion rate of each marker was used during the first two periods. Markers were continuously infused from d 11 to 17 in the first square and from 14 to 20 in the second square of cannulated cows. Digesta flow leaving the rumen was quantified using the system of alternating vacuum and pressure for collecting digesta from the omasal canal that was originally developed by Huhtanen et al. (1997) and modified by Ahvenjärvi et al. (2000). By this approach, 400-ml spot samples were collected from a tube passed through the ruminal cannula and positioned in the omasal canal. Samples were taken four times daily at 2-h intervals on d 15 to 17 (first square) and on d 18 to 20 (second square). Sampling was at 0000, 0200, 0400, 0600 (d-1), 0800, 1000, 1200, 1400 (d-2), and 1600, 1800, 2000 , and $2200 \mathrm{~h}$ (d 3), such that the samples taken represented the 24 -h feeding cycle over the $3 \mathrm{~d}$. In our application of this technique, we confirmed the location of the sample tube in the omasal canal at each sampling. Occasionally, it was necessary to reposition the tube in the omasum and also to unblock the end of the tube, possibly because of the large amount of corn silage in our diets. Each 400-ml omasal spot sample was divided into subsamples of 100 and $300 \mathrm{ml}$. Formaldehyde [1 ml of $40 \%$ (wt/vol)] was added to the $100-\mathrm{ml}$ subsample. Subsamples were stored frozen as they were collected and pooled over all sampling times to yield one 1.2-L and one 3.6-L composite from each cow in each period. Pooled subsamples were stored at $-20^{\circ} \mathrm{C}$ until processed.

The 1.2-L pooled omasal composites were thawed at room temperature and centrifuged $\left(176 \times g, 4^{\circ} \mathrm{C}, 5 \mathrm{~min}\right)$; supernatants were carefully decanted and recentrifuged $\left(11,300 \times g, 4^{\circ} \mathrm{C}, 30 \mathrm{~min}\right)$. Supernatants were decanted and discarded, and pellets were resuspended in $100 \mathrm{ml}$ of McDougall's buffer and recentrifuged $\left(11,300 \times g, 4^{\circ} \mathrm{C}\right.$, $30 \mathrm{~min})$. The resulting bacterial pellets were stored at $-20^{\circ} \mathrm{C}$ until freeze-dried and ground with a mortar and pestle for later analysis. The 3.6-L pooled omasal composites were thawed at room temperature and separated into three digesta phases as follows. Samples were squeezed through one layer of cheesecloth, and solids retained on the cheesecloth were defined as the large particle phase (LP). The filtrate was centrifuged at $10,000 \times g\left(4^{\circ} \mathrm{C}, 15 \mathrm{~min}\right)$, and the supernatant was carefully decanted from the pellet. The supernatant was defined as the fluid phase (FP) and the pellet as the small particle phase (SP). The separated phases were frozen, freeze-dried, then ground through a 1-mm screen (Wiley mill) for later marker analysis. Concentrations of $\mathrm{Co}$, 
$\mathrm{Yb}$, and indigestible NDF in LP and SP and of Co and $\mathrm{Yb}$ in FP were used to mix DM from freeze-dried FP, $\mathrm{SP}$, and LP in the correct proportions to reconstitute the omasal true digesta (OTD) flowing out of the rumen based on the triple-marker method of France and Siddons (1986). Concentration of the principle marker for each phase was distinctly higher in its respective digesta phase: Mean Co concentrations in FP were 3.2 and 6.0 times greater than in SP and LP; mean $\mathrm{Yb}$ concentrations in SP were 3.3 and 3.6 times greater than in FP and LP; and mean indigestible NDF concentration in LP was 6.8 times greater than in SP. This allowed successful application of the France and Siddons triple-marker approach. At the time of the morning feeding on $\mathrm{d} 17$ (first square) and 20 (second square), marker infusions were stopped and samples of whole ruminal contents were taken at 0 (prefeeding), 1, 2, 4, 6, 8, 12, and $24 \mathrm{~h}$ postfeeding. These samples were stored at $-20^{\circ} \mathrm{C}$, freeze-dried, ground through 1-mm screen (Wiley mill), and analyzed for $\mathrm{DM}$ and $\mathrm{Co}$ and $\mathrm{Yb}$ concentrations. Declines in Co and $\mathrm{Yb}$ concentrations were used to estimate ruminal passage rates of DM in FP and SP, respectively.

An additional sample of whole ruminal contents was taken at $6 \mathrm{~h}$ postfeeding, squeezed through two layers of cheesecloth to yield about $1000 \mathrm{ml}$ of strained ruminal fluid for use in isolation of protozoa. To this sample, 100 $\mathrm{ml}$ of $10 \%$ (wt/vol) glucose solution was added, mixed well, poured into a separatory funnel, and allowed to sediment for $2 \mathrm{~h}$. A distinct layer of protozoal sediment was slowly drawn off, and the upper phase was discarded. The separated layer was stored at $-20^{\circ} \mathrm{C}$ until freeze-dried and ground with a mortar and pestle.

Bacterial, protozoal, TMR, and protein concentrate samples were analyzed for total $\mathrm{N}$ using a combustion assay (Leco FP-2000 N Analyzer; Leco Instruments, Inc., St. Joseph, MI). Neutral detergent insoluble N (NDIN) and acid detergent insoluble N (ADIN) also were determined in protein supplements and OTD samples. Indigestible NDF was determined in LP, SP, TMR, and fecal samples (but not in FP; Ahvenjarvi et al., 2000), as follows. Samples $(0.35 \mathrm{~g})$ were weighted into duplicate 5$\times 10$-cm dacron bags with $6-\mu \mathrm{m}$ pore size, incubated in the rumens of two cows for $12 \mathrm{~d}$, rinsed with water, then subjected to conventional NDF analysis (Hintz et al., 1995). For Co and $\mathrm{Yb}$ analysis, 1-g samples of LP, SP, and whole ruminal contents were ashed at $500^{\circ} \mathrm{C}$ for 16 $\mathrm{h}$ and then solubilized in $10 \mathrm{ml}$ of concentrated $\mathrm{HCl}$ and a solution of $0.6 \%(\mathrm{wt} / \mathrm{wt}) \mathrm{LiOH}$ to a final mass of 100 g. Samples of FP $(0.5 \mathrm{ml})$ were diluted with $5 \mathrm{ml}$ of concentrated $\mathrm{HCl}$ and $94.5 \mathrm{ml}$ of $\mathrm{LiOH}$ solution before analysis. Concentrations of $\mathrm{Co}$ and $\mathrm{Yb}$ were analyzed by direct current plasma emission spectroscopy (SpectraSpan V; Fison Instruments, Valencia, CA; Combs, 1985).
The OTD, bacterial, protozoal, protein concentrates, and TMR samples were hydrolyzed for $24 \mathrm{~h}$ at $110^{\circ} \mathrm{C}$ in sealed vials under a $\mathrm{N}_{2}$ atmosphere in $6 \mathrm{~N} \mathrm{HCl}$ containing $0.1 \% \mathrm{wt} / \mathrm{vol}$ phenol (Mason et al., 1979). The ratio of sample $\mathrm{N}$ to acid used in hydrolysis was $1 \mathrm{mg}$ total $\mathrm{N}$ per $5 \mathrm{ml}$ of $6 \mathrm{~N} \mathrm{HCl}$. After hydrolysis, samples were cooled, $\mathrm{HCl}$ removed by evaporation, and the residue redissolved in $\mathrm{pH} 2.2$ sample buffer containing norleucine as internal standard. Analysis of individual and total AA, and total AA N (TAAN), was conducted using ion exchange chromatography with ninhydrin detection (Beckman 6300 Amino Acid Analyzer, Beckman Instruments, Inc., Palo Alto, CA). Aqueous extracts were prepared in distilled water from weekly composites of TMR (Muck, 1987) and analyzed for NPN using a combustion assay (Mitsubishi TN-05 Nitrogen Analyzer; Mitsubishi Chemical Corp., Tokyo). Samples of OTD, bacteria, protozoa, protein concentrates, and TMR extracts also were analyzed for $\mathrm{NH}_{3}$ and total free AA (Broderick and Kang, 1980) using flow-injection analysis (QuikChem 8000 FIA, Lachat Instruments, Milwaukee, WI). Total purines were determined in samples of OTD, bacteria, and protozoa using both the HPLC and spectrophotometric methods of Makkar and Becker (1999). There was insufficient material to conduct purine analyses on protozoal samples from individual cows; therefore, equal amounts of DM were pooled across all cows in all periods to yield three protozoal composites for purine assay. Protozoal purine:NAN ratios were reported to be unaffected by diet (Firkins et al., 1987; Volden et al., 1999). Moreover, there was no effect of diet on AA composition of protozoal isolates in the present study. Therefore, pooling protozoal samples for purine assay likely did not compromise our findings. Duplicate samples of isolated bacteria and protozoa (37.5 mg DM) and digesta (100 mg DM) were hydrolyzed with $2 \mathrm{M} \mathrm{HClO}_{4}$ at $95^{\circ} \mathrm{C}$ for $1 \mathrm{~h}$. After cooling, phosphate buffer was added, and samples were returned to the $95^{\circ} \mathrm{C}$ bath for $15 \mathrm{~min}$. Samples were centrifuged at $3,000 \times \mathrm{g}$ for $10 \mathrm{~min}$, and one aliquot of supernatant was taken for each of the HPLC and spectrophotometer analyses.

During sample preparation for spectrophotometry, we noted that silver nitrate pellets were poorly formed after centrifugation and found that increasing centrifugation speed from $25,000 \times g$ to $50,000 \times g$ improved average recovery of RNA equivalents. Therefore, centrifugation at $50,000 \times g$ was used for silver nitrate precipitation in all further spectrophotometric analyses of total purines. Additional comment on this modification is presented in the Results and Discussion. The HPLC system (Shimadzu Class-VP, version 5.03, Shimadzu Scientific Instruments, Inc., Columbia, MD) consisted of an SIL10ADvp autosampler, two LC-10ADvp pumps, an SCL10 Avp system controller, a 250- $\times 4.6-\mathrm{mm}$ Inertsil ODS- 
3 column (MetaChem Technologies Inc., Torrance, CA), and an SPD-M10Avp photodiode array detector. Allopurinol and caffeine were used as internal standards for HPLC. Recovery of purines was estimated by carrying Torula yeast through both assays. The RNA alone was hydrolyzed, and concentrations of adenine and guanine (HPLC) were measured; this RNA also was used as standard for spectrophotometry. Bacterial and omasal samples were analyzed for purines with and without addition of known amounts of the standard RNA to determine purine recoveries in both assays. For HPLC, mean $( \pm C V)$ recoveries of adenine and guanine added as yeast RNA were, respectively, $105 \%( \pm 3.6)$ and $104 \%( \pm 2.7)$ in bacterial samples and $106 \%( \pm 0.2)$ and $109 \%( \pm 0.3)$ in OTD samples. For spectrophotometry, mean $( \pm \mathrm{CV})$ recoveries of added yeast RNA were $90 \%$ ( \pm 4.8 ) in bacterial samples and $96 \%( \pm 4.2)$ in OTD samples. For the HPLC method, mean coefficients of variation between replicates were 3.6 and $0.23 \%$ for bacterial and OTD samples, respectively. For the spectrophotometric method, mean coefficients of variation between replicates were 7.7 and $6.3 \%$ for bacterial and OTD samples, respectively. Effects of $\operatorname{diet}(P=0.44)$, as well as period and square $(\alpha=0.25)$, on bacterial TAAN:purine and NAN:purine ratios were not significant in the model; therefore, mean ratios were used to compute microbial $\mathrm{N}$ fractions in OTD samples.

Proportions of nutrients of bacterial, protozoal, and dietary origin in omasal digesta also were estimated using a linear programming approach. The Solver function of Excel (Windows Small Business, Microsoft, Redland, WA) was used to apportion flows of NAN and TAAN among RUP, bacteria, and protozoa from each cow in each period using Standard Simplex linear programming with the nonnegative constraint option, using the linear programming method described by Shabi et al. (2000).

\section{Calculations}

Basal diet A contained the same basal ingredients as the other four diets except for the protein supplement. Amounts $(\mathrm{g} / \mathrm{d})$ of omasal TAAN and NAN flow originating from microbial protein and RUP on all diets were estimated using purines, determined by both assays, as the microbial marker (based on bacteria isolated from the FP) and linear programming. Omasal TAAN and NAN flows originating from RUP in experimental proteins were computed by difference. Ruminal escape of TAAN and NAN originating from the diet was calculated:

$$
\text { RUP }_{\text {Total }}, \mathrm{g} / \mathrm{d}=\text { Omasal flow, } \mathrm{g} / \mathrm{d}-\text { Microbial flow, } \mathrm{g} / \mathrm{d}
$$

The $\mathrm{RUP}_{\text {Total }}$ for basal diet A would derive only from basal ingredients; $\mathrm{RUP}_{\mathrm{Total}}$ for the other four diets would derive from both basal ingredients plus supplemental protein. Proportionate escape of TAAN and NAN from the basal ingredients in diet A was calculated:

$$
\begin{gathered}
\mathrm{RUP}_{\text {Basal A }}, \%=\left[\mathrm{RUP}_{\text {Total }}, \mathrm{g} / \mathrm{d}(\text { basal } \operatorname{diet} \mathrm{A}) / \text { Intake},\right. \\
\mathrm{g} / \mathrm{d}(\text { basal } \operatorname{diet} \mathrm{A})] \times 100
\end{gathered}
$$

Ruminal escape of TAAN and NAN from the basal ingredients in protein supplemented diets B, C, D, and E was assumed to be equivalent to that of $\operatorname{diet} \mathrm{A}$ and was calculated for each diet:

$$
\begin{gathered}
\mathrm{RUP}_{\mathrm{Basal}}, \mathrm{g} / \mathrm{d}=\text { Intake of basal ingredients, } \\
\mathrm{g} / \mathrm{d} \times\left[\left(\mathrm{RUP}_{\text {Basal A }}, \%\right) / 100\right]
\end{gathered}
$$

Ruminal escape of TAAN and NAN from each of the four protein supplements was calculated:

$$
\begin{aligned}
& \mathrm{RUP}_{\text {Protein }}, \mathrm{g} / \mathrm{d}=\mathrm{RUP}_{\text {Total }}, \mathrm{g} / \mathrm{d}-\mathrm{RUP}_{\text {Basal }} \text {, } \\
& \text { g/d }
\end{aligned}
$$

The proportion of ruminal escape of NAN and TAAN from each protein supplement was calculated:

Escape (Protein supplement), $\%=\left(\mathrm{RUP}_{\text {Protein }}\right.$, $\mathrm{g} / \mathrm{d} /$ Intake (Protein supplement), $\mathrm{g} / \mathrm{d}) \times 100$

Efficiency of microbial NAN synthesis in the rumen was calculated:

Microbial NAN efficiency, $\mathrm{g} / \mathrm{kg}=$ microbial NAN omasal flow, g/d/OMTDR, kg/d

where OMTDR was the OM truly digested in the rumen.

\section{Statistical Analysis}

Passage rates were estimated by regressing the ln of $\mathrm{Co}$ and $\mathrm{Yb}$ concentrations on time using a nonlinear method for determining slope (Littell et al., 1996; SAS, 1999); these slopes were equated to the rates of passage $(/ \mathrm{h})$ of the DM in FP $(\mathrm{Co})$ and $\mathrm{SP}(\mathrm{Yb})$. All data were analyzed using proc mixed in SAS (1999). The following model was fitted: $\mathrm{Y}_{\mathrm{ijkl}}=\mu+\mathrm{S}_{\mathrm{i}}+\mathrm{P}_{\mathrm{j}}+\mathrm{Vk}_{(\mathrm{i})}+\mathrm{T}_{\mathrm{l}}+\mathrm{ST}_{\mathrm{il}}+$ $\mathrm{E}_{\mathrm{ijk}}$, where $\mathrm{Y}_{\mathrm{ijkl}}=$ dependant variable, $\mu=$ overall mean, $\mathrm{S}_{\mathrm{i}}=$ effect of square $\mathrm{i}, \mathrm{P}_{\mathrm{j}}=$ effect of period $\mathrm{j}, \mathrm{Vk}_{(\mathrm{i})}=$ effect of cow $\mathrm{k}$ (within square $\mathrm{i}$ ), $\mathrm{T}_{1}=$ effect of treatment $1, \mathrm{ST}_{\mathrm{il}}$ $=$ interaction between square $\mathrm{i}$ and treatment $\mathrm{l}$, and $\mathrm{E}_{\mathrm{ijkl}}$ $=$ residual error. All terms were considered fixed, except for $\mathrm{Vk}_{(\mathrm{i})}$ and $\mathrm{E}_{\mathrm{ijk}}$, which were considered random. The interaction term $\mathrm{ST}_{\mathrm{il}}$ was removed from the model when $P>0.25$. Differences between least squares means were 
Table 1. Composition of protein concentrates. ${ }^{1}$

\begin{tabular}{lcccc}
\hline Item & SSBM & ESBM & BM & CGM \\
\hline Total N, \% of DM & 8.84 & 7.83 & 16.21 & 10.43 \\
TAAN, \% of DM & 10.1 & 8.6 & 19.2 & 11.2 \\
NDIN, \% total N & 5.7 & 10.7 & 6.4 & 8.1 \\
ADIN, \% of total N & 2.0 & 2.3 & 1.2 & 6.4 \\
NAN, \% of total N & 99.92 & 99.95 & 99.95 & 99.89 \\
Amino acid N, ${ }^{3} \%$ of TAAN & & & & \\
Asp & 9.4 & 9.4 & 8.4 & 5.3 \\
Thr & 3.6 & 3.6 & 4.2 & 3.2 \\
Ser & 5.2 & 5.3 & 5.0 & 5.6 \\
Glu & 13.3 & 13.3 & 5.8 & 15.9 \\
Pro & 4.6 & 4.7 & 3.2 & 8.6 \\
Gly & 5.9 & 6.1 & 6.1 & 10.6 \\
Ala & 5.2 & 5.3 & 9.5 & 2.3 \\
Cys & 1.9 & 1.8 & 0.9 & 3.8 \\
Val & 3.9 & 3.9 & 6.7 & 1.7 \\
Met & 0.9 & 1.0 & 0.9 & 3.0 \\
Ile & 3.4 & 3.5 & 0.4 & 13.4 \\
Leu & 6.2 & 6.3 & 10.0 & 3.3 \\
Tyr & 2.3 & 2.4 & 1.6 & 4.2 \\
Phe & 3.3 & 3.3 & 4.6 & 4.1 \\
His & 5.3 & 5.3 & 12.8 & 2.5 \\
Lys & 7.8 & 7.5 & 11.0 & 8.2 \\
Arg & 17.7 & 17.2 & 8.9 & \\
\hline
\end{tabular}

${ }^{1} \mathrm{ADIN}=$ acid detergent insoluble $\mathrm{N}, \mathrm{BM}=$ blood meal; $\mathrm{CGM}$ = corn gluten meal; $\mathrm{ESBM}$ = expeller soybean meal; NDIN = neutral detergent insoluble N; SSBM = solvent soybean meal; TAAN = total AA N.

${ }^{2}$ Proportion of total $\mathrm{N}$ recovered as $\mathrm{N}$ in individual $\mathrm{AA}$ in acid hydrolysates of each protein.

${ }^{3}$ Proportion of the TAAN detected as $\mathrm{N}$ in the individual AA in acid hydrolysates of each protein concentrate.

reported only if the F-test for treatment was significant at $\alpha=0.05$.

\section{RESULTS AND DISCUSSION}

\section{Feed Composition}

Composition of the four protein concentrates fed in this study are in Table 1 . Concentrations of NDIN and ADIN determined in SSBM, ESBM, and CGM were somewhat higher than those reported by the NRC (2001). Proportions of Cornell fraction B3 (NDIN minus ADIN; Sniffen et al., 1992) also were higher in SSBM and CGM, averaging, respectively, 3.7 and $1.7 \%$ of total N. Proportion of Cornell fraction B3 in ESBM, 8.4\% of total N, was comparable to the value reported in NRC (2001) tables. The NRC (2001) reports no NDIN or ADIN data for BM. The NAN contents accounted for virtually all of the $\mathrm{N}$ in the four proteins. As expected, SSBM and ESBM had nearly identical patterns for individual AA as proportions of TAAN. When expressed in the same units as in NRC tables ( $\mathrm{g} \mathrm{AA} / 100 \mathrm{~g} \mathrm{CP}$ ), concentrations observed for most individual AA among the four proteins were within $\pm 15 \%$ of NRC (2001) values. Exceptions for the nine essential AA (Trp was not determined) were Ile in $\mathrm{BM}$, which was only $0.66 \mathrm{~g} / 100 \mathrm{~g}$ CP [52\% of the NRC (2001) mean], and Arg and Cys, which averaged 120 and $129 \%$ of NRC (2001) values for the four proteins. It is not known why the Ile concentrations observed in BM were low and Arg values appeared relatively high. Losses of Cys from oxidation during acid hydrolysis prior to AA determination can be extensive (Mason et al., 1979); Cys recovery during the hydrolysis step may have been more effective than average in the present trial.

Chemical composition of the TMR fed in this study are in Table 2. Addition of one of the protein concentrates increased dietary $\mathrm{N}$ from $2.88 \%$ to an average of $3.58 \%$ of DM; protein supplement accounted for a mean of $22.4 \%$ of dietary CP. Adding intact protein diluted the $\mathrm{CP}$ equivalent from alfalfa silage and urea; thus, proportions of total N present as NPN and free AA N were reduced in the four diets supplemented with protein concentrate.

Composition data on isolated omasal bacteria and ruminal protozoa are in Table 3. Total $\mathrm{N}$ and NAN contents, expressed on a DM basis, were lower than were found in earlier studies; however, mean OM contents of both microbial fractions also were lower (Hristov and Broderick, 1994; 1996). The bacteria and protozoa were isolated by differential centrifugation including washing with buffer salts, which may have increased their ash content. Omasal bacteria were $8.7 \%$ NAN on a OM basis, similar to earlier reports (Cecava et al., 1990; Clark et al., 1992; Hristov and Broderick, 1996). Sedimentation after uptake of soluble sugars, as was used in isolation of protozoa in this trial, results in dilution of protozoal NAN with carbohydrate. Protozoal NAN content was 
Table 2. Nutrient composition of diets. ${ }^{1}$

\begin{tabular}{|c|c|c|c|c|c|}
\hline \multirow{3}{*}{$\begin{array}{l}\text { Item } \\
\text { Protein supplement }\end{array}$} & \multicolumn{5}{|c|}{ Diet } \\
\hline & A & B & $\mathrm{C}$ & $\mathrm{D}$ & $\mathrm{E}$ \\
\hline & None & SSBM & ESBM & $\mathrm{BM}$ & CGM \\
\hline Total N, \% of DM & 2.88 & 3.50 & 3.59 & 3.70 & 3.54 \\
\hline Protein supplement, \% of total $\mathrm{N}$ & & 22.8 & 21.7 & 24.2 & 20.9 \\
\hline $\mathrm{NPN},{ }^{2} \%$ of total $\mathrm{N}$ & 55.3 & 43.9 & 42.0 & 40.0 & 39.0 \\
\hline Free AA N, ${ }^{3} \%$ of total $\mathrm{N}$ & 21.9 & 17.9 & 17.5 & 16.0 & 17.5 \\
\hline NAN, $\%$ of total $N$ & 93.3 & 94.2 & 96.9 & 97.6 & 97.9 \\
\hline TAAN,${ }^{4} \%$ of total $\mathrm{N}$ & 48.0 & 58.0 & 52.6 & 62.9 & 56.9 \\
\hline $\mathrm{TAAN}^{4} \%$ of NAN & 51.4 & 61.6 & 54.3 & 64.4 & 58.1 \\
\hline \multicolumn{6}{|l|}{ Amino acid $\mathrm{N},{ }^{5} \%$ of TAAN } \\
\hline Asp & 6.0 & 7.4 & 7.8 & 7.3 & 6.1 \\
\hline Thr & 3.9 & 3.7 & 3.9 & 3.7 & 3.6 \\
\hline Ser & 4.4 & 4.6 & 4.8 & 4.6 & 4.7 \\
\hline Glu & 9.6 & 10.6 & 10.5 & 7.8 & 11.4 \\
\hline Pro & 8.2 & 6.8 & 6.1 & 6.3 & 8.9 \\
\hline Gly & 7.3 & 7.0 & 7.2 & 6.9 & 6.3 \\
\hline Ala & 15.1 & 12.0 & 11.6 & 12.8 & 13.8 \\
\hline Cys & 3.0 & 2.7 & 2.4 & 2.2 & 2.9 \\
\hline Val & 5.4 & 4.9 & 5.0 & 5.9 & 4.8 \\
\hline Met & 1.3 & 1.2 & 1.3 & 1.1 & 1.4 \\
\hline Ile & 3.6 & 3.5 & 3.6 & 2.1 & 3.3 \\
\hline Leu & 8.8 & 7.6 & 7.6 & 9.3 & 10.2 \\
\hline Tyr & 2.4 & 2.4 & 2.7 & 1.9 & 2.6 \\
\hline Phe & 3.6 & 3.5 & 3.7 & 4.0 & 3.7 \\
\hline His & 4.5 & 4.7 & 4.5 & 8.4 & 4.4 \\
\hline Lys & 4.8 & 5.8 & 6.1 & 7.4 & 4.0 \\
\hline Arg & 8.0 & 11.6 & 11.3 & 8.4 & 7.8 \\
\hline
\end{tabular}

\footnotetext{
${ }^{1} \mathrm{BM}$ = blood meal; CGM = corn gluten meal; ESBM = expeller soybean meal; SSBM = solvent soybean meal; TAAN $=$ total AA N

${ }^{2}$ Proportion of total N soluble in $10 \%$ (wt/vol) trichloroacetic acid (Muck, 1987).

${ }^{3}$ Free AA $\mathrm{N}=$ total free AA, $\mathrm{mmol} \times(40.3 \mathrm{mg}$ of $\mathrm{N} / \mathrm{mmol}$ of total free AA) (Broderick, 1987).

${ }^{4}$ Total $\mathrm{N}$ determined as 17 protein $\mathrm{AA}$ in acid hydrolysates of each diet.

${ }^{5}$ Proportion of TAAN detected in individual AA in acid hydrolysates of each diet.
}

$6.3 \%$ of the OM. Robinson et al. (1996) reported a mean of $6.5 \%$ total $\mathrm{N}$ in ruminal protozoal OM.

\section{Omasal Nutrient Flows}

As expected, cows fed basal diet A had the lowest ( $P$ $\leq 0.05$ ) omasal flows of total N, NAN, Asp, Thr, Ser, Glu, Pro, Gly, Ala, Val, Leu, Phe, His, Lys, Arg, and TAAN compared to cows fed the four diets supplemented with protein concentrates (Table 4). Total $\mathrm{N}$ and NAN flows were not different among the cows receiving the protein supplements, ranging from 612 to $661 \mathrm{~g} / \mathrm{d}$ (total N) and 595 to $648 \mathrm{~g} / \mathrm{d}$ (NAN). Flows of Met were not significantly different between cows fed the basal and SSBM diets (A and B). Also, Cys flow was not significantly different among cows fed the basal, SSBM, and BM diets (A, B, and D). Cows fed the BM diet (D) had the highest flows of Val, Phe, His, and Lys. Omasal TAAN flow was greatest on the BM diet (D), intermediate on the ESBM and CGM diets (C and E), and lowest on the SSBM $\operatorname{diet}(\mathrm{B})$. Intake of TAAN was numerically greater for the BM diet (D), probably because it contained more $\mathrm{CP}$ and thus more TAAN (Table 2). Greater TAAN flow for cows fed the BM diet (D) did not result in the highest production of milk and milk components (Reynal and Broderick, 2003). This could have been due to a lower intestinal digestibility of $\mathrm{BM}$, compared to the other supplements. The NRC (2001) assigned intestinal digestibilities of 93, 93, 80, and 94\% for the RUP fractions of SSBM, ESBM, BM, and CGM, respectively. These estimates of omasal AA flow (Table 4), the AA concentrations in the diets (Table 2), and in isolated bacteria and protozoa (Table 3) also were used in linear programming analysis (Shabi et al., 2000) to estimate proportions of TAAN and NAN derived from RUP and contributed by ruminal microbes.

\section{Estimates of Microbial $\mathbf{N}$}

During sample preparation for spectrophotometric purine analysis, we observed that the centrifugation step did not yield a stable pellet. Increasing centrifugation speed in the silver nitrate precipitation step from $25,000 \times g$ to $50,000 \times g$ increased apparent RNA content of bacterial and OTD samples by 30 and $12 \%$, respectively. These disproportionate increases in recovery lowered estimates of bacterial flow by 12 to $26 \%$ and 
REYNAL ET AL.

Table 3. Mean composition of omasal bacteria and ruminal protozoa.

\begin{tabular}{|c|c|c|c|c|}
\hline Item & $\begin{array}{l}\text { Omasal } \\
\text { bacteria }\end{array}$ & SD & $\begin{array}{l}\text { Ruminal } \\
\text { protozoa }\end{array}$ & SD \\
\hline $\mathrm{OM}, \%$ of $\mathrm{DM}$ & 85.3 & 2.6 & 90.0 & 2.4 \\
\hline Total N, \% of DM & 7.43 & 0.46 & 5.74 & 0.98 \\
\hline NAN, \% of DM & 7.42 & 0.46 & 5.66 & 0.98 \\
\hline \multicolumn{5}{|c|}{$\mathrm{N}$ :purine ratio (HPLC method) ${ }^{1}$} \\
\hline NAN/purines, g/mmol & 0.98 & 0.06 & 1.08 & 0.02 \\
\hline TAAN/purines, g/mmol ${ }^{2}$ & 0.58 & 0.06 & 0.70 & 0.01 \\
\hline \multicolumn{5}{|c|}{$\mathrm{N}$ :purine ratio (spectrophotometric method) ${ }^{3}$} \\
\hline NAN/RNAeq, g/g & 0.96 & 0.09 & 0.97 & 0.13 \\
\hline TAAN/RNAeq, g/g & 0.57 & 0.06 & 0.63 & 0.03 \\
\hline $\mathrm{TAAN}^{4} \%$ of TN & 59.6 & 5.9 & 61.5 & 4.6 \\
\hline \multicolumn{5}{|l|}{ Amino acid $\mathrm{N},{ }^{5} \%$ of TAAN } \\
\hline Asp & 9.9 & 0.3 & 11.3 & 0.7 \\
\hline Thr & 5.2 & 0.2 & 4.7 & 0.2 \\
\hline Ser & 5.0 & 0.2 & 4.6 & 0.4 \\
\hline Glu & 9.9 & 0.3 & 10.8 & 0.5 \\
\hline Pro & 3.7 & 0.2 & 3.5 & 0.3 \\
\hline Gly & 7.9 & 0.3 & 6.6 & 0.4 \\
\hline Ala & 9.1 & 0.5 & 5.7 & 0.8 \\
\hline Cys & 1.1 & 0.2 & 1.4 & 0.4 \\
\hline Val & 4.9 & 1.0 & 4.4 & 0.4 \\
\hline Met & 1.3 & 0.5 & 1.5 & 0.4 \\
\hline Ile & 4.3 & 0.2 & 5.0 & 0.4 \\
\hline Leu & 7.0 & 0.2 & 7.0 & 0.5 \\
\hline Tyr & 3.4 & 0.3 & 3.3 & 0.6 \\
\hline Phe & 4.3 & 0.3 & 4.3 & 0.6 \\
\hline His & 4.4 & 0.3 & 4.3 & 0.6 \\
\hline Lys & 6.4 & 0.8 & 14.0 & 2.8 \\
\hline Arg & 12.1 & 0.4 & 11.3 & 0.4 \\
\hline
\end{tabular}

resulted in poor relationships between the microbial TAAN and NAN flows estimated using high-speed vs. low-speed centrifugation (Figure 1). Higher recoveries and better agreement between HPLC and the results obtained at high-speed $(r=0.94$ vs. $r=0.61)$ indicated that purine recovery was substantially improved by increasing centrifugation force at this stage of the spectrophotometric assay.

Intakes of TAAN and NAN (computed from feed intake and composition) plus omasal flows of microbial protein and RUP, estimated using all three approaches, are summarized in Table 5. Compared to those made using HPLC and spectrophotometric purine determinations, mean yields estimated by linear programming analysis were, respectively, 63 and $83 \mathrm{~g} / \mathrm{d}$ greater for microbial TAAN and NAN (Table 5). Note that the linear programming results represented the sum of bacterial plus protozoal flows. Thus, RUP accounted for greater proportions of dietary TAAN and NAN using results from the purine assays. Based on NRC (2001) tables, RUP contents of the five diets should have ranged from $20(\operatorname{diet} \mathrm{A})$ to $35 \%(\mathrm{BM} \operatorname{diet} \mathrm{D})$ of total $\mathrm{CP}$ (assuming RUP of urea $=0$ ). Overall estimates for RUP based on NAN flows ranged from 15 (diet A) to $29 \%$ (BM $\operatorname{diet} \mathrm{D})$ by linear programming, $22(\operatorname{diet} \mathrm{A})$ to $33 \%$ (diets D and E) by HPLC purine analysis, and 18 (diet A) to $33 \%$ (CGM diet E) by spectrophotometric purine analysis. This suggested that linear programming analysis overestimated microbial protein and underestimated RUP on these diets. The HPLC method was considered more reliable for determination of purines for quantifying microbial protein because variation was only about half that found using the total spectrophotometric assay (with high-speed centrifugation). Microbial TAAN flows estimated using both the spectrophotometric and linear programming methods were regressed on microbial TAAN flow estimated by HPLC (Figure 2). Agreement between the two purine assays was good ( $r=0.94)$, with the slope about $10 \%$ above the diagonal. Although the correlation between results obtained by linear programming and HPLC analysis were only slightly poorer $(r=0.84)$, the slope of 1.4 
Table 4. Omasal nutrient flows. ${ }^{1}$

\begin{tabular}{|c|c|c|c|c|c|c|c|}
\hline \multirow{3}{*}{$\begin{array}{l}\text { Item } \\
\text { Protein supplement }\end{array}$} & \multicolumn{7}{|c|}{ Diet } \\
\hline & A & B & $\mathrm{C}$ & $\mathrm{D}$ & $\mathrm{E}$ & & \\
\hline & None & SSBM & ESBM & BM & CGM & SE & $P>\mathrm{F}^{2}$ \\
\hline $\mathrm{DM}, \mathrm{kg} / \mathrm{d}$ & 13.9 & 14.4 & 15.0 & 14.6 & 14.5 & 0.8 & 0.68 \\
\hline $\mathrm{OM}, \mathrm{kg} / \mathrm{d}$ & 10.9 & 11.3 & 11.9 & 11.4 & 11.5 & 0.6 & 0.54 \\
\hline Total N, g/d & $524^{\mathrm{b}}$ & $612^{\mathrm{a}}$ & $651^{\mathrm{a}}$ & $655^{\mathrm{a}}$ & $661^{\mathrm{a}}$ & 32 & $<0.01$ \\
\hline NAN, g/d & $513^{\mathrm{b}}$ & $595^{\mathrm{a}}$ & $632^{\mathrm{a}}$ & $642^{\mathrm{a}}$ & $648^{\mathrm{a}}$ & 34 & $<0.01$ \\
\hline \multicolumn{8}{|c|}{ Amino acid $\mathrm{N}$ flows (g/day) } \\
\hline Asp & $30.6^{\mathrm{b}}$ & $37.0^{\mathrm{a}}$ & $39.8^{\mathrm{a}}$ & $40.2^{\mathrm{a}}$ & $36.6^{\mathrm{a}}$ & 1.8 & 0.01 \\
\hline Thr & $16.3^{\mathrm{b}}$ & $19.2^{\mathrm{a}}$ & $20.3^{\mathrm{a}}$ & $20.6^{\mathrm{a}}$ & $19.5^{\mathrm{a}}$ & 1.0 & 0.03 \\
\hline Ser & $16.2^{\mathrm{c}}$ & $19.2^{\mathrm{b}}$ & $20.7^{\mathrm{ab}}$ & $22.3^{\mathrm{a}}$ & $20.6^{\mathrm{ab}}$ & 1.0 & $<0.01$ \\
\hline Glu & $33.5^{\mathrm{b}}$ & $39.6^{\mathrm{a}}$ & $43.6^{\mathrm{a}}$ & $40.2^{\mathrm{a}}$ & $44.6^{\mathrm{a}}$ & 2.0 & $<0.01$ \\
\hline Pro & $13.2^{\mathrm{c}}$ & $15.6^{\mathrm{b}}$ & $16.5^{\mathrm{b}}$ & $16.5^{\mathrm{b}}$ & $19.3^{\mathrm{a}}$ & 0.8 & $<0.01$ \\
\hline Gly & $24.9^{\mathrm{b}}$ & $29.0^{\mathrm{a}}$ & $30.5^{\mathrm{a}}$ & $31.2^{\mathrm{a}}$ & $28.9^{\mathrm{a}}$ & 1.4 & 0.03 \\
\hline Ala & $28.8^{\mathrm{c}}$ & $33.0^{\mathrm{b}}$ & $34.6^{\mathrm{ab}}$ & $38.1^{\mathrm{a}}$ & $36.8^{\mathrm{ab}}$ & 1.7 & $<0.01$ \\
\hline Cys & $5.1^{\mathrm{b}}$ & $5.9^{\mathrm{ab}}$ & $6.6^{\mathrm{a}}$ & $5.8^{\mathrm{ab}}$ & $6.7^{\mathrm{a}}$ & 0.4 & 0.04 \\
\hline Val & $15.4^{\mathrm{c}}$ & $18.6^{\mathrm{b}}$ & $19.0^{\mathrm{b}}$ & $22.8^{\mathrm{a}}$ & $18.8^{\mathrm{b}}$ & 0.9 & $<0.01$ \\
\hline Met & $5.5^{\mathrm{b}}$ & $6.0^{\mathrm{ab}}$ & $6.4^{\mathrm{a}}$ & $6.3^{\mathrm{a}}$ & $6.6^{\mathrm{a}}$ & 0.3 & 0.05 \\
\hline Ile & $12.5^{\mathrm{c}}$ & $14.8^{\mathrm{ab}}$ & $15.8^{\mathrm{a}}$ & $13.8^{\mathrm{bc}}$ & $15.0^{\mathrm{ab}}$ & 0.7 & 0.02 \\
\hline Leu & $22.6^{\mathrm{c}}$ & $26.6^{\mathrm{b}}$ & $27.6^{\mathrm{b}}$ & $33.0^{\mathrm{a}}$ & $31.7^{\mathrm{a}}$ & 1.5 & $<0.01$ \\
\hline Tyr & 11.6 & 13.0 & 14.0 & 13.2 & 13.9 & 0.7 & 0.08 \\
\hline Phe & $13.0^{\mathrm{c}}$ & $15.0^{\mathrm{b}}$ & $15.5^{\mathrm{b}}$ & $17.6^{\mathrm{a}}$ & $16.1^{\mathrm{ab}}$ & 0.8 & $<0.01$ \\
\hline His & $13.8^{\mathrm{c}}$ & $16.4^{\mathrm{b}}$ & $16.7^{\mathrm{b}}$ & $26.2^{\mathrm{a}}$ & $16.7^{\mathrm{b}}$ & 0.9 & $<0.01$ \\
\hline Lys & $25.4^{\mathrm{c}}$ & $30.5^{\mathrm{b}}$ & $32.7^{b}$ & $37.3^{\mathrm{a}}$ & $29.5^{\mathrm{b}}$ & 1.4 & $<0.01$ \\
\hline Arg & $35.7^{\mathrm{b}}$ & $42.7^{\mathrm{a}}$ & $45.5^{\mathrm{a}}$ & $45.4^{\mathrm{a}}$ & $41.1^{\mathrm{a}}$ & 2.2 & 0.01 \\
\hline Total AA-N & $324^{\mathrm{c}}$ & $378^{\mathrm{b}}$ & $411^{\mathrm{ab}}$ & $431^{\mathrm{a}}$ & $415^{\mathrm{ab}}$ & 18 & $<0.01$ \\
\hline
\end{tabular}

${ }^{1} \mathrm{BM}=$ blood meal; CGM = corn gluten meal; ESBM = expeller soybean meal; $\mathrm{SSBM}=$ solvent soybean meal.

${ }^{2}$ Probability of a significant effect of diet.

a,b,c Means with different superscripts differ $(P<0.05)$.

suggested that these results deviated substantially from each other. Similar relationships were observed when microbial NAN flows were compared (data not shown). Although the linear programming approach allowed separate estimates of bacterial and protozoal protein, we interpreted these results to indicate that overall means from the spectrophotometric and HPLC assays were comparable but that microbial $\mathrm{N}$ flows estimated, using linear programming, were less accurate and overestimated. Findings based on the two purine methods were used to estimate TAAN and NAN flows contributed by RUP from each protein concentrate.

Despite the apparent divergence of results based on purine analyses and linear programming, all three methods gave similar estimates of microbial NAN yield per unit of OM truly digested in the rumen (OMTDR; Table 5). Overall means from HPLC, spectrophotometric, and linear programming analyses were, respectively, 32, 33, and $35 \mathrm{~g}$ microbial $\mathrm{N}$ per kilogram OMTDR. Klusmeyer et al. (1991) fed cows diets similar to $\mathrm{B}$ and $\mathrm{E}$ at similar intakes (21 to $22 \mathrm{~kg} \mathrm{DM} / \mathrm{d}$ ) and observed mean yields of about $35 \mathrm{~g}$ microbial $\mathrm{N}$ per kilogram OMTDR. Regression of microbial NAN flows on OMTDR from all three methods yielded comparable correlation coefficients (range 0.43 to 0.52 ) and slopes, which are alternative estimates of microbial yield (range 27.1 to $27.9 \mathrm{~g}$ NAN per kilogram OMTDR; Figure 3). However, the greater apparent microbial NAN flows obtained by linear programming were reflected in a somewhat larger intercept. Clark et al. (1992) regressed microbial $\mathrm{N}$ production on ruminal OM digestion data from 22 trials and obtained a slope very similar to the present study, about $25 \mathrm{~g}$ microbial $\mathrm{N}$ per kilogram OMTDR, and a correlation coefficient $=0.25$. Dietary TDN content, discounted using actual DMI (NRC, 2001), ranged from 64.2 to $65.2 \%$. Ruminal microbial N production was computed using these discounted TDN values in the NRC (2001) model, and the values regressed on our estimates of microbial $\mathrm{N}$ flow (i.e., without the minor correction for $\mathrm{NH}_{3} \mathrm{~N}$ ) determined with the three methods (Figure 4). Slopes from all three regressions deviated substantially from the diagonal, ranging from 0.24 (linear programming) to 0.30 (HPLC). Microbial N synthesis predicted by the NRC model ranged from only 193 to $362 \mathrm{~g} \mathrm{~N}$ per day. Ranges of our estimates of microbial N were 216 to $655 \mathrm{~g}$ N per day by HPLC, 239 to $717 \mathrm{~g}$ N per day by the spectrophotometric assay, and 302 to $740 \mathrm{~g} \mathrm{~N}$ per day by linear programming. The NRC (2001) attributed much more of the predicted difference in protein flow from the rumen to the effects of diet on RUP than were detected in our experiment. 

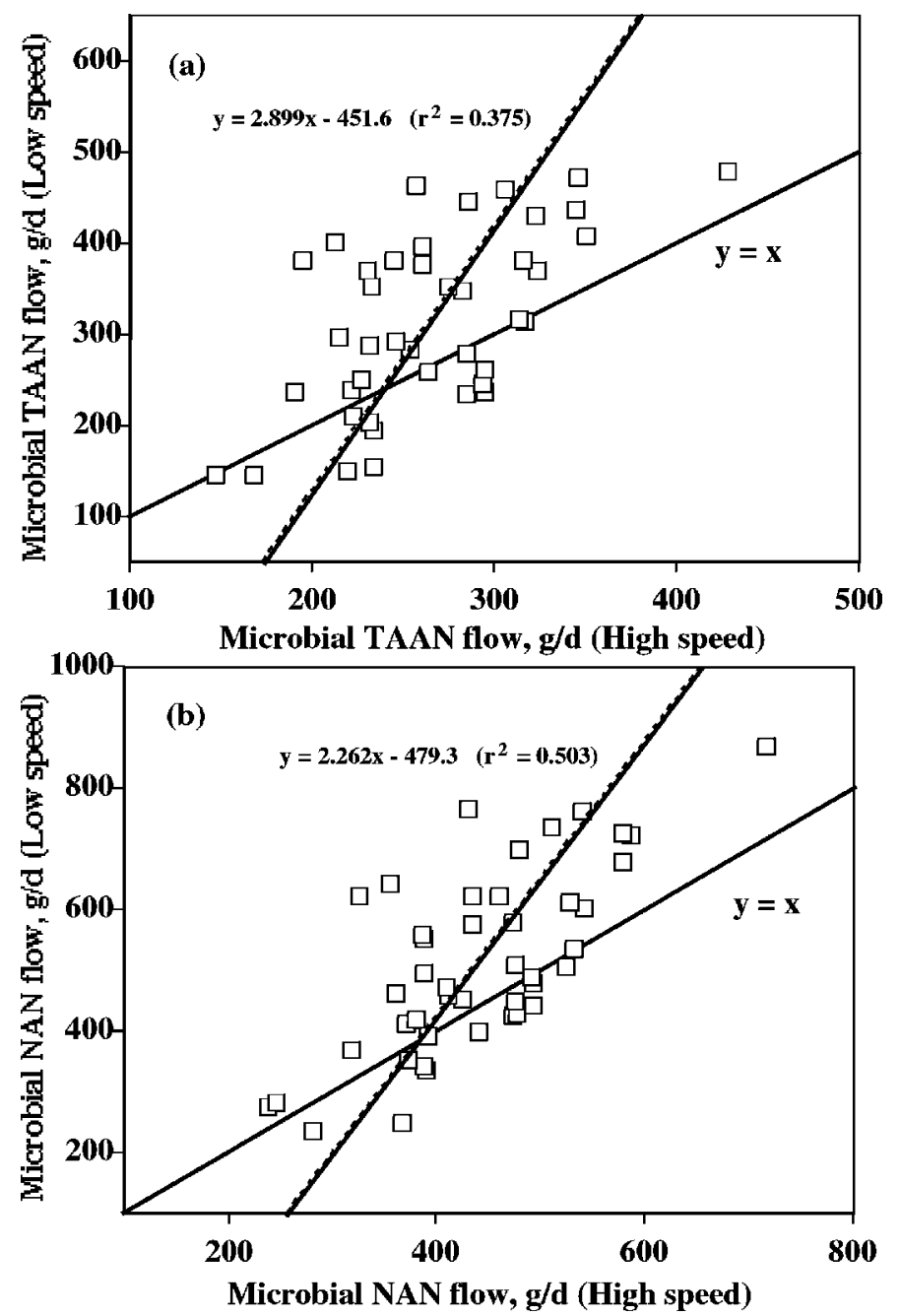

Figure 1. Relationships of omasal flow of microbial total AA N (TAAN) (a) and NAN (b) determined after centrifuging samples (during the silver nitrate precipitation step of the total purine assay; Makkar and Becker, 1999) at low speed $(25,000 \times$ g; y-axis $)$ or high speed $(50,000 \times g ; x$-axis $)$. The broken lines describe the linear regression equations; the solid lines represents the $\mathrm{y}=\mathrm{x}$ diagonal.

Protozoal N, which could only be estimated using linear programming, accounted for 19 to $29 \%$ of total TAAN flow and 20 to $28 \%$ of total NAN flow; proportions of omasal $\mathrm{N}$ flow from protozoa were highest on BM, intermediate on the two SBM, and lowest on CGM and the basal diet (Table 5). These estimates were quite high relative to literature reports. For example, Robinson et al. (1996), feeding dairy cows rations with 55:45 forage to concentrate ratio and supplemented with SBM, BM, or urea, reported that protozoal NAN did not differ among CP sources and averaged $12.9 \%$ of duodenal NAN flow. Protozoa contribute to purine flow out of the rumen, but use of purine microbial markers may lead to underestimation of total microbial $\mathrm{N}$ be- cause of higher N:purine ratios in protozoa (Broderick and Merchen, 1992). For example, Firkins et al. (1987) found that the NAN:purine ratio of fluid and particle associated bacteria averaged only $56 \%$ of that for protozoa. However, Volden et al. (1999) observed N:purine ratios of fluid and particle associated bacteria that were, respectively, 89 and $117 \%$ of those of liquid associated protozoa. Analyses of bacterial samples plus the three composites of rumen protozoa yielded mean NAN:purine ratios for bacteria and protozoa of 0.98 and $1.06 \mathrm{mg}$ NAN per micromole total purines (HPLC) and 0.96 and $0.97 \mathrm{~g}$ NAN per gram RNA (spectrophotometry). Using the proportions of bacterial and protozoal NAN from linear programming and NAN:purine ratios determined by HPLC and spectrophotometric methods, microbial NAN flows would be, respectively, only 2.6 and $0.1 \%$ higher than those computed using the bacterial ratios alone.

The linear programming method, based as it is on the AA patterns of the diet, omasal digesta, and ruminal microbes, requires accurate composition data on all fractions. Volden and Harstad (1998) reported that the addition of formaldehyde to ruminal samples significantly reduced the total AA detected in bacteria by $11 \%$; Tyr, Lys, Met, and Phe were most affected, which resulted in significant changes in the AA profiles of the isolated bacteria. The use of formaldehyde in the present trial could have resulted in AA losses, thus, altering AA patterns of isolated omasal bacteria and contributing to overestimation of $\mathrm{N}$ flows in fractions of microbial origin. Moreover, contamination of bacterial samples with feed particles would have resulted in apparent bacterial AA profiles being more similar to dietary AA patterns, and also led to an overestimation of the bacterial $\mathrm{N}$ flows by linear programming.

When purines are used as microbial markers, it is necessary to assume that all the dietary purines are degraded in the rumen and only those of microbial origin pass to the lower tract. Perez et al. (1996) found purine base concentrations of 27, 27, and $7 \mu \mathrm{mol} / \mathrm{g} \mathrm{DM}$ in alfalfa hay, SBM, and corn grain, respectively. Based on in situ degradation kinetics measured in sheep, and assuming a fractional passage rate of $0.05 / \mathrm{h}$, they estimated that 4,17 , and $8.5 \%$ of the purines in, respectively, alfalfa hay, SBM, and corn grain could escape the rumen. If we assume that our SBM diet had similar purines concentrations and degradation kinetics as those reported by Perez et al. (1996) and a passage rate for dietary DM of $0.05 / \mathrm{h}$, then contamination of omasal digesta with dietary purines would have resulted in a $6.5 \%$ overestimation of microbial NAN flow on the SBM diet. Liquid- and particle-associated bacteria have been reported to differ in N:purine ratios (Cecava et al., 1990; Doreau et al., 1991), with those for particle-associated 
Table 5. Results from comparing three different methods for quantifying microbial protein flow at the omasum on estimates of in vivo ruminal escape of protein supplements and microbial protein yields. ${ }^{1}$

\begin{tabular}{|c|c|c|c|c|c|c|c|}
\hline \multirow[b]{2}{*}{$\begin{array}{l}\text { Item } \\
\text { Protein supplement }\end{array}$} & \multicolumn{7}{|c|}{ Diet } \\
\hline & A & B & C & $\mathrm{D}$ & $\begin{array}{l}\mathrm{E} \\
\mathrm{CGM}\end{array}$ & $\mathrm{SF}$ & $P>\mathrm{F}^{2}$ \\
\hline \multicolumn{8}{|l|}{ TAAN intake, $\mathrm{g} / \mathrm{d}$} \\
\hline Total & 265 & 397 & 406 & 444 & 402 & & \\
\hline from basal ingredients & 265 & 248 & 250 & 263 & 259 & 12 & 0.67 \\
\hline from protein supplement & & $149^{\mathrm{b}}$ & $156^{\mathrm{b}}$ & $181^{\mathrm{a}}$ & $143^{\mathrm{b}}$ & 6 & $<0.01$ \\
\hline \multicolumn{8}{|l|}{ NAN intake, g/d } \\
\hline Total & 513 & 663 & 744 & 709 & 721 & & \\
\hline from basal ingredients & 513 & 508 & 586 & 533 & 552 & 26 & 0.10 \\
\hline from protein supplement & & $148^{\mathrm{ab}}$ & $161^{\mathrm{a}}$ & $158^{\mathrm{a}}$ & $139^{b}$ & 6 & $<0.01$ \\
\hline TAAN omasal flow, g/d & $324^{\mathrm{c}}$ & $378^{\mathrm{b}}$ & $411^{\mathrm{ab}}$ & $431^{\mathrm{a}}$ & $415^{\mathrm{ab}}$ & 18 & $<0.01$ \\
\hline NAN omasal flow, g/d & $513^{b}$ & $595^{\mathrm{a}}$ & $632^{\mathrm{a}}$ & $642^{\mathrm{a}}$ & $648^{\mathrm{a}}$ & 32 & $<0.01$ \\
\hline \multicolumn{8}{|l|}{ Linear programming analysis ${ }^{3}$} \\
\hline Bacteria & 210 & 245 & 233 & 186 & 234 & 15 & 0.10 \\
\hline Protozoa & $74^{\mathrm{c}}$ & $93^{\mathrm{bc}}$ & $101^{\mathrm{b}}$ & $130^{\mathrm{a}}$ & $81^{\mathrm{bc}}$ & 7 & $<0.01$ \\
\hline RUP $_{\text {Total }} 4$ & $40^{\mathrm{d}}$ & $66^{\mathrm{cd}}$ & $85^{\mathrm{bc}}$ & $135^{\mathrm{a}}$ & $103^{\mathrm{ab}}$ & 14 & $<0.01$ \\
\hline \multicolumn{8}{|l|}{ TAAN flow, $\%$ of omasal flow } \\
\hline Bacteria & $65^{\mathrm{a}}$ & $59^{\mathrm{ab}}$ & $55^{\mathrm{b}}$ & $41^{\mathrm{c}}$ & $55^{\mathrm{b}}$ & 3 & $<0.01$ \\
\hline Protozoa & $23^{\mathrm{b}}$ & $24^{\mathrm{ab}}$ & $24^{\mathrm{ab}}$ & $29^{\mathrm{a}}$ & $19^{\mathrm{b}}$ & 2 & 0.03 \\
\hline $\mathrm{RUP}_{\text {Total }}$ & $12^{\mathrm{d}}$ & $16^{\text {cd }}$ & $21^{\mathrm{bc}}$ & $30^{\mathrm{a}}$ & $25^{\mathrm{ab}}$ & 3 & $<0.01$ \\
\hline RUP $_{\text {Basal }} A,{ }^{5} \%$ of intake & 15.1 & & & & & & \\
\hline $\mathrm{RUP}_{\text {Basal, }}{ }^{6} \mathrm{~g} / \mathrm{d}$ & $(40)$ & 37 & 38 & 40 & 39 & & \\
\hline $\mathrm{RUP}_{\text {Protein, }}{ }^{7} \mathrm{~g} / \mathrm{d}$ & & 29 & 47 & 95 & 64 & & \\
\hline Escape (Protein supplement), ${ }^{8} \%$ & & 19 & 30 & 52 & 45 & & \\
\hline \multicolumn{8}{|l|}{ NAN flow, $g / d$} \\
\hline Bacteria & 341 & 394 & 405 & 305 & 362 & 26 & 0.08 \\
\hline Protozoa & $113^{\mathrm{c}}$ & $144^{\mathrm{bc}}$ & $158^{\mathrm{b}}$ & $198^{\mathrm{a}}$ & $131^{\mathrm{bc}}$ & 11 & $<0.01$ \\
\hline $\mathrm{RUP}_{\text {Total }}{ }^{4}$ & $78^{\mathrm{b}}$ & $116^{\mathrm{b}}$ & $126^{\mathrm{b}}$ & $208^{\mathrm{a}}$ & $186^{\mathrm{a}}$ & 23 & $<0.01$ \\
\hline \multicolumn{8}{|l|}{ NAN flow, $\%$ of omasal flow } \\
\hline Bacteria & $64^{\mathrm{a}}$ & $59^{\mathrm{ab}}$ & $58^{\mathrm{ab}}$ & $43^{\mathrm{c}}$ & $53^{\mathrm{b}}$ & 3 & $<0.01$ \\
\hline Protozoa & $21^{\mathrm{b}}$ & $24^{\mathrm{ab}}$ & $23^{\mathrm{ab}}$ & $28^{\mathrm{a}}$ & $20^{\mathrm{b}}$ & 2 & 0.03 \\
\hline RUP $_{\text {Total }}$ & $14^{\mathrm{c}}$ & $18^{\mathrm{c}}$ & $19^{\mathrm{bc}}$ & $29^{\mathrm{a}}$ & $27^{\mathrm{ab}}$ & 3 & $<0.01$ \\
\hline $\operatorname{RUP}_{\text {Basal }} \mathrm{A},{ }^{5} \%$ of intake & 15.2 & & & & & & \\
\hline $\mathrm{RUP}_{\text {Basal, }}{ }^{6} \mathrm{~g} / \mathrm{d}$ & $(78)$ & 77 & 89 & 81 & 84 & & \\
\hline $\operatorname{RUP}_{\text {Protein }}{ }^{6} \mathrm{~g} / \mathrm{d}$ & & 39 & 37 & 127 & 102 & & \\
\hline Escape (Protein supplement) ${ }^{8} \%$ & & 26 & 23 & 80 & 73 & & \\
\hline $\begin{array}{l}\text { Bacterial + protozoal NAN synthesis, } \\
\text { g NAN/kg OMTDR }\end{array}$ & 34 & 35 & 34 & 36 & 35 & 1 & 0.75 \\
\hline \multicolumn{8}{|l|}{ Purine analysis by $\mathrm{HPLC}^{9}$} \\
\hline \multicolumn{8}{|l|}{ TAAN flow, g/d } \\
\hline Microbial $^{3}$ & 238 & 255 & 262 & 244 & 245 & 15 & 0.65 \\
\hline $\mathrm{RUP}_{\text {Total }}{ }^{4}$ & 86 & 123 & 149 & 187 & 170 & & \\
\hline $\mathrm{RUP}_{\text {Basal }} \mathrm{A},{ }^{5} \%$ of intake & 32.5 & & & & & & \\
\hline $\mathrm{RUP}_{\text {Basal, }}{ }^{6} \mathrm{~g} / \mathrm{d}$ & $(86)$ & 80 & 81 & 85 & 84 & & \\
\hline $\mathrm{RUP}_{\text {Protein, }}{ }^{7} \mathrm{~g} / \mathrm{d}$ & & 43 & 68 & 102 & 86 & & \\
\hline Escape (Protein supplement), ${ }^{8} \%$ & & 29 & 44 & 56 & 60 & & \\
\hline \multicolumn{8}{|l|}{ NAN flow, g/d } \\
\hline Microbial & 400 & 428 & 439 & 410 & 411 & 25 & 0.65 \\
\hline $\mathrm{RUP} 4$ & 113 & 167 & 193 & 232 & 237 & & \\
\hline $\operatorname{RUP}_{\text {Basal }} \mathrm{A},{ }^{5} \%$ of intake & 22.0 & & & & & & \\
\hline $\mathrm{RUP}_{\text {Basal }}{ }^{6} \mathrm{~g} / \mathrm{d}$ & $(113)$ & 113 & 129 & 120 & 127 & & \\
\hline RUP $_{\text {Protein }}{ }^{7} \mathrm{~g} / \mathrm{d}$ & & 54 & 64 & 112 & 110 & & \\
\hline Escape (Protein supplement), ${ }^{8} \%$ & & 36 & 40 & 69 & 76 & & \\
\hline $\begin{array}{l}\text { Microbial NAN efficiency, } \\
\text { g NAN/kg OMTDR }\end{array}$ & 32 & 32 & 32 & 32 & 32 & 1 & 0.99 \\
\hline \multicolumn{8}{|c|}{$\begin{array}{l}\text { Total purines by spectrophotometric analysis }{ }^{10} \\
\text { TAAN flow, g/d }\end{array}$} \\
\hline Microbial & 250 & 277 & 267 & 263 & 247 & 20 & 0.64 \\
\hline \multirow{2}{*}{$\mathrm{RUP}_{\text {Total }}$} & 74 & 101 & 144 & 168 & 168 & & \\
\hline & & & & & & \multicolumn{2}{|c|}{ Continued } \\
\hline
\end{tabular}


Table 5 (continued). Results from comparing three different methods for quantifying microbial protein flow at the omasum on estimates of in vivo ruminal escape of protein supplements and microbial protein yields. ${ }^{1}$

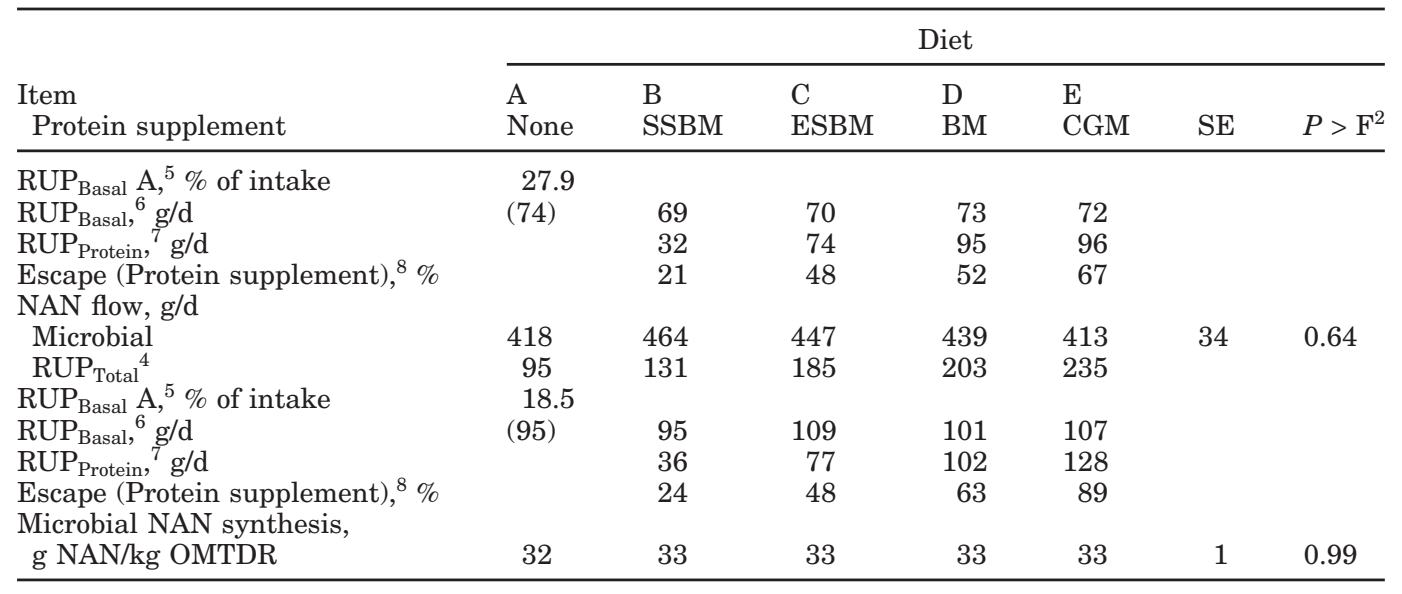

${ }^{1} \mathrm{BM}=$ blood meal; CGM = corn gluten meal; ESBM = expeller soybean meal; OMTDR = organic matter truly digested in the rumen; SSBM = solvent soybean meal; TAAN = total AA N.

${ }^{2}$ Probability of a significant effect of diet.

${ }^{3}$ Estimated using linear programming (Solver function of Excel, Windows) based on the AA pattern of isolated bacteria, protozoa, omasal true digesta, and the five TMR.

${ }^{4} \mathrm{RUP}_{\text {Total }}$ flow, $\mathrm{g} / \mathrm{d}=$ Omasal flow, g/d - Microbial flow, $\mathrm{g} / \mathrm{d}$.

${ }^{5} \mathrm{RUP}_{\text {Basal A }}, \%=\left[\mathrm{RUP}_{\text {Total }}, \mathrm{g} / \mathrm{d}(\operatorname{diet} \mathrm{A}) / \mathrm{Intake}, \mathrm{g} / \mathrm{d}(\operatorname{diet} \mathrm{A})\right] \times 100$.

${ }^{6} \mathrm{RUP}_{\mathrm{Basal}}, \mathrm{g} / \mathrm{d}=$ Intake (basal ingredients), $\mathrm{g} / \mathrm{d} \times\left[\left(\mathrm{RUP}_{\mathrm{Basal}} \mathrm{A}, \%\right) / 100\right]$. Values in parentheses are the RUP $_{\text {Basal }}$ observed for basal diet A.

${ }^{7} \mathrm{RUP}_{\text {Protein }}, \mathrm{g} / \mathrm{d}=\mathrm{RUP}_{\text {Total }}, \mathrm{g} / \mathrm{d}-\mathrm{RUP}_{\text {Basal }}, \mathrm{g} / \mathrm{d}$.

${ }^{8}$ Escape (protein supplement), $\%=$ (TAAN flow from protein supplement/TAAN intake from protein supplement) $\times 100$.

${ }^{9}$ Estimated from adenine + guanine determined using the HPLC method of Makkar and Becker (1999).

${ }^{10}$ Estimated from total purines determined using the spectrophotometer method from Makkar and Becker (1999) with maximum speed of centrifugation $(50,000 \times g)$.

bacteria being up to $20 \%$ higher. Moreover, particleassociated bacteria may account for about $50 \%$ of the total bacterial flow from the rumen (Hristov and Broderick, 1996). If in our trial, particle-associated bacteria did account for $50 \%$ of the bacterial $\mathrm{CP}$ and had a N:purine ratio $20 \%$ higher than for liquid-associated bacteria, then bacterial $\mathrm{N}$ flows would have been underestimated by $10 \%$. These potential errors due to differential $\mathrm{N}$ :purine ratios in different microbial fractions, as well as ruminal escape of dietary purines, may or may not have been offsetting.

\section{In Vivo Estimates of RUP}

It was necessary to assume that degradation of the basal protein components were equal on all five diets to estimate ruminal escape of each protein supplement. Santos et al. (1998) reported that supplementation with very undegradable proteins could reduce microbial $\mathrm{N}$ synthesis and microbial activity in the rumen. Urea was added to all diets to prevent a lack of RDP and yields of microbial TAAN and NAN were found not different (Table 5). Thus, ruminal degradative activity likely was similar among diets. Depressed DMI also could decrease passage rate, increase retention time, and result in greater microbial degradation of feed protein. Although DMI on diet A was $1.7 \mathrm{~kg} / \mathrm{d}$ less than the average for the supplemented diets, rates of passage estimated using either $\mathrm{Co}$ or $\mathrm{Yb}$ were unaffected by diet (Reynal and Broderick, 2003). Therefore, it seems probable that the basal protein components in all diets were degraded to a similar extent.

As discussed above, the estimates of extent of ruminal degradation of the four protein concentrates based on the two purine assays were considered more accurate than those based on linear programming. Four degradation values were obtained for each of the proteins from TAAN and NAN flows using the HPLC and spectrophotometric data. The means ( \pm SD) for these RUP estimates were (Table 5) SSBM, 27\% ( \pm 6$)$, ESBM, 45\% $( \pm 4)$, $\mathrm{BM}, 60 \%( \pm 7)$, and CGM, $73( \pm 13)$. There have been relatively few reports of in vivo estimates of ruminal escape of dietary protein. Moreover, published data have been highly variable among trials, probably because the extent of protein degradation varies with dietary and animal factors and due to errors associated 


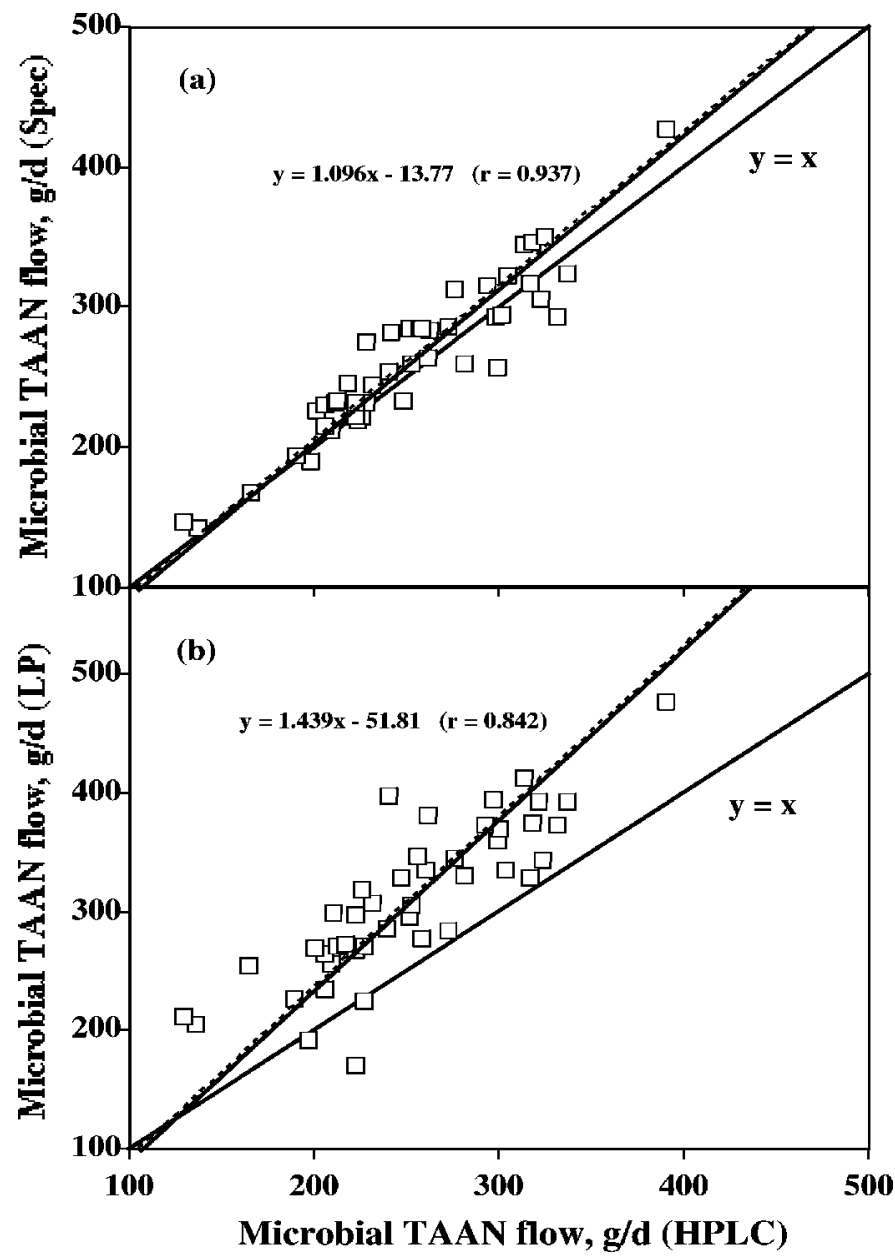

Figure 2. Regressions of microbial TAAN flow determined using the spectrophotometric assay (Spec) for total purines (a) and linear programming (LP) (b) on microbial TAAN flow determined using the HPLC purine assay. The broken lines describe the linear regression equations; the solid lines represents the $\mathrm{y}=\mathrm{x}$ diagonal.

with the analysis of microbial protein and digesta flow (Satter, 1986). In an extensive literature review, Satter (1986) summarized in vivo estimates of ruminal protein escape for a number of individual feedstuffs. The mean escape from 10 studies for SSBM was 27\% (range of 10 to $61 \%$ ); mean escape from two studies for BM was $68 \%$ (individual values 54 and $82 \%$ ); and mean escape from three studies for CGM was 55\% (range 46 to $61 \%$ ). No results were reported for ESBM. Mean estimates of in vivo escape in the present trial were the same for SSBM and 8 percentage units lower for BM; however, our estimate for CGM was 18 percentage units higher than the mean reported by Satter (1986). The RUP values reported by the NRC (2001) for these four proteins (at $\mathrm{DM}$ intake $=4 \%$ of BW) were SSBM, $43 \%$, ESBM, $69 \%$, BM, 78\%, and CGM, 75\%. Except for CGM, the NRC values were substantially greater than our estimates,

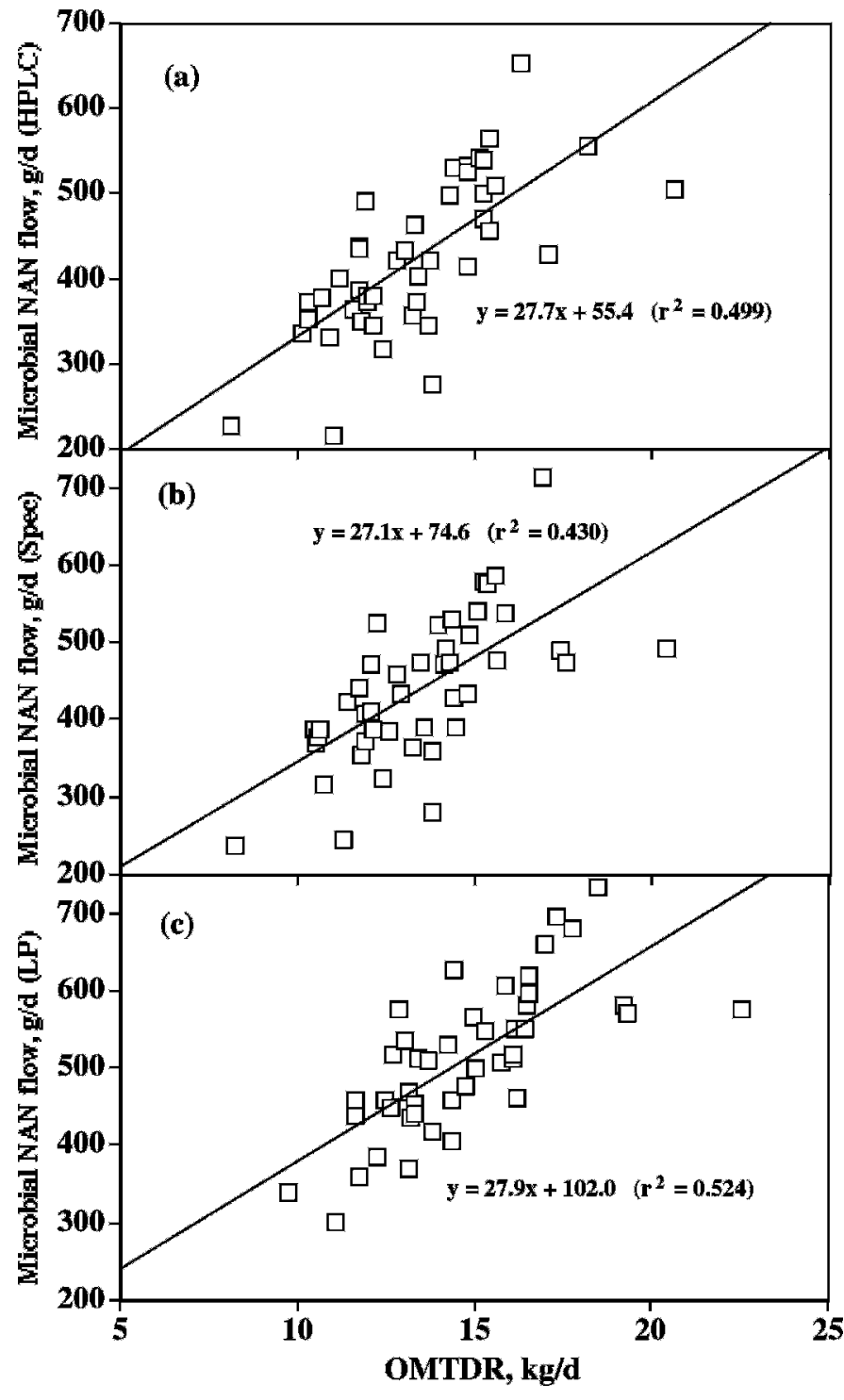

Figure 3. Regressions of microbial NAN flow determined using the HPLC purine assay (a), the spectrophotometric assay (Spec) for total purines (b), and linear programming (LP) (c) on organic matter truly digested in the rumen (OMTDR). Slopes of the regressions represent an estimate of microbial NAN yield per unit of OMTDR.

averaging about 20 percentage units higher for the other three proteins. Our RUP estimates may have been low compared to NRC (2001) values because of relatively high microbial $\mathrm{N}$ flows and the $73 \%$ escape determined for CGM may, in fact, have been exceptional. The ADIN content of CGM was $6.4 \%$ of total N, vs. a mean of $3 \%$ in NRC (2001) tables, suggesting that the CGM fed in the current study could have sustained greater than average heat damage.

\section{SUMMARY}

Modification of a spectrophotometric total purine assay improved purine recoveries from bacterial and 


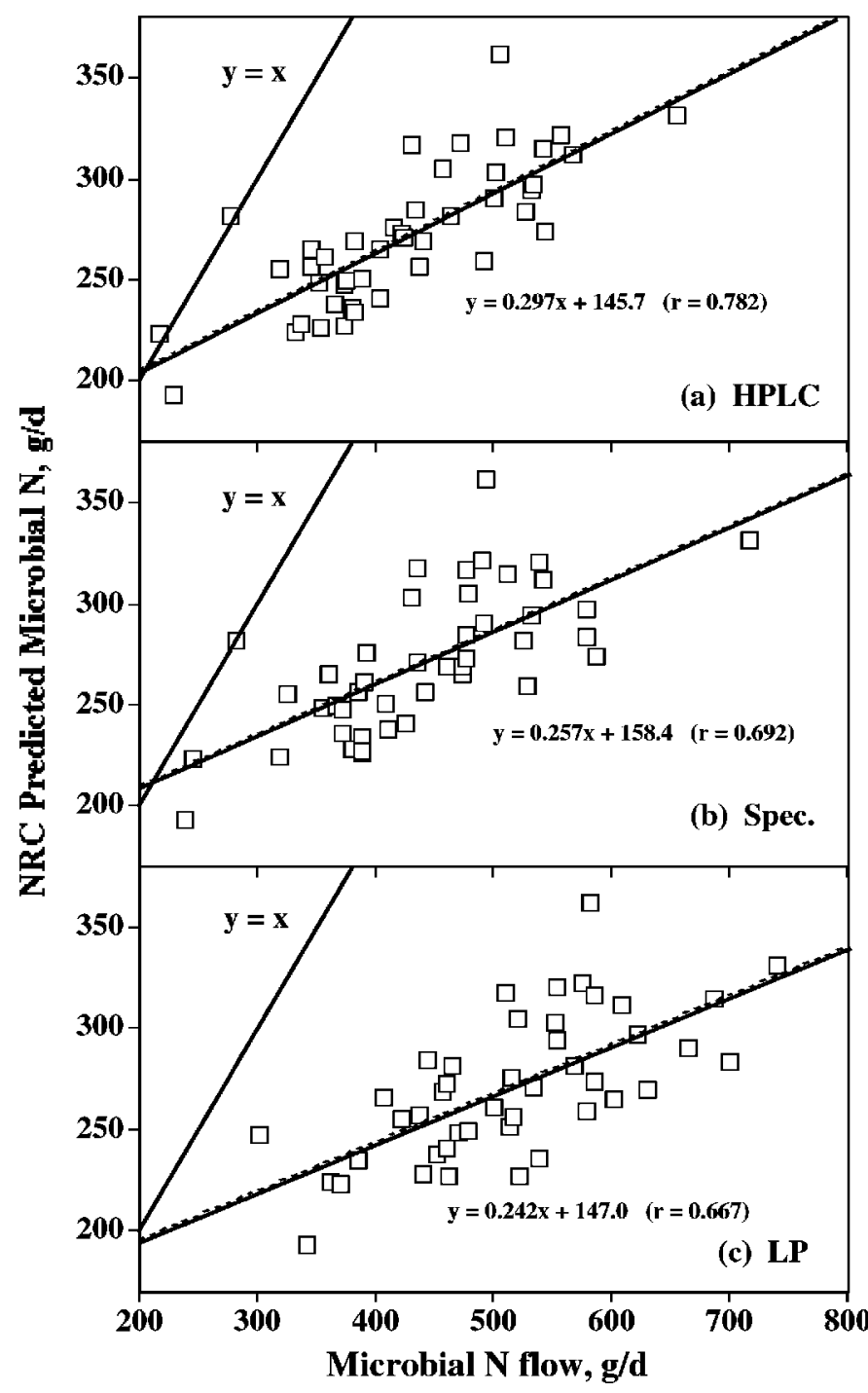

Figure 4. Relationships of microbial $\mathrm{N}$ production, predicted from intake of discounted TDN using the NRC (2001) model, to microbial $\mathrm{N}$ production determined using the HPLC purine assay (a), the spectrophotometric assay (Spec) for total purines (b), and linear programming (LP) (c). The broken lines describe the linear regression equations; the solid lines represents the $\mathrm{y}=\mathrm{x}$ diagonal.

omasal digesta samples and increased method precision. Microbial protein flows determined with omasal sampling using an HPLC purine method were highly correlated with those measured by the modified assay $(\mathrm{r}=0.94)$. Use of linear programming analysis, based on the AA patterns of the diet and isolated bacteria and protozoa, appeared to overestimate microbial protein and underestimate RUP in omasal digesta. The NRC (2001) equations predicted microbial flows that were 50 to $89 \%$, and RUP flows that were 77 to $99 \%$, of those estimated using the purine assays. Mean extents of in vivo degradation computed for SSBM, ESBM, and BM based on the purine microbial markers averaged $20 \%$ lower than RUP values reported in NRC (2001) tables but were similar to those reported in the literature. The RUP estimate for CGM was about equal to that of the NRC (2001). Both purine-based assays appeared to yield reliable estimates of microbial protein flow from the rumen. Better microbial isolation techniques may result in improved accuracy of the linear programming approach.

\section{ACKNOWLEDGMENTS}

The authors thank Rick Walgenbach and the farm crew for harvesting and storing the feeds and Len Strozinski and the barn crew for in animal care and sampling at the US Dairy Forage Center Research Farm (Prairie du Sac, WI); Brad Ricker, Wendy Radloff, Mary Becker, and Diane Amundson for conducting laboratory analyses; and Peter Crump for assisting with statistical analyses.

\section{REFERENCES}

Aharoni, Y., and H. Tagari. 1991. Use of nitrogen-15 determinations of purine nitrogen fraction of digesta to define nitrogen metabolism traits in the rumen. J. Dairy Sci. 74:2540.

Ahvenjärvi, S., A.Vanhatalo, P. Huhtanen, and T. Varvikko. 2000. Determination of reticulo-rumen and whole-stomach digestion in lactating cows by omasal canal or duodenal sampling. Br. J. Nutr. 83:67-77.

Broderick, G. A., and J. H. Kang. 1980. Automated simultaneous determination of ammonia and total amino acids in ruminal fluid and in vitro media. J. Dairy Sci. 63:64-75.

Broderick, G. A., and N. R. Merchen. 1992. Markers for quantifying microbial protein synthesis in the rumen. J. Dairy Sci. 75:2618-2632.

Cecava, M. J., N. R. Merchen, L. C. Gay, and L. L. Berger. 1990 Composition of ruminal bacteria harvested from steers as influenced by dietary energy level, feeding frequency, and isolation techniques. J. Dairy Sci. 73:2480-2488.

Clark, J. H., T. H. Klusmeyer, and M. R. Cameron. 1992. Symposium: Nitrogen metabolism and amino acid nutrition in dairy cattle: Microbial protein synthesis and flows of nitrogen fractions to the duodenum of dairy cows. J. Dairy Sci. 75:2304-2323.

Craig, W. M., D. R. Brown, G. A. Broderick, and D. B. Ricker. 1987. Post-prandial compositional changes of fluid- and particle-associated ruminal microorganisms. J. Anim. Sci. 65:1042-1048.

Doreau, M., F. Legay, and D. Bauchart. 1991. Effect of source and level of supplemental fat on total and ruminal organic matter and nitrogen digestion in dairy cows. J. Dairy Sci. 74:2233-2242.

Firkins, J. L., L. L. Berger, N. R. Merchens, G. C. Fahey, Jr., and R. L. Mulvaney. 1987. Ruminal nitrogen metabolism in steers as affected by feed intake and dietary urea concentration. J. Dairy Sci. 70:2302.

France, J., and R. C. Siddons. 1986. Determination of digesta flow by continuous marker infusion. J. Theor. Biol. 121:105-119.

Hintz, R. W., D. R. Mertens, and K. A. Albrecht. 1995. Effects of sodium sulfite on recovery and composition of detergent fiber and lignin. J. AOAC 78:16-22.

Hristov, A., and G. A. Broderick. 1994. In vitro determination of ruminal protein degradability using (15N)ammonia to correct for microbial nitrogen uptake. J. Anim. Sci.72:1344-1354.

Hristov, A. N., and G. A. Broderick. 1996. Synthesis of microbial protein in ruminally cannulated cows fed alfalfa silage, alfalfa hay, or corn silage. J. Dairy Sci. 79:1627-1637. 
Huhtanen, P., S. Kaustell, and S. Jaakkola. 1994. The use of internal markers to predict total digestibility and duodenal flow of nutrients in cattle given six different diets. Anim. Feed Sci. Technol. 48:211-227.

Huhtanen P., P. G. Brotz, and L. D. Satter. 1997. Omasal sampling technique for assessing fermentative digestion in the forestomach of dairy cows. J. Animal Sci. 75:1380-1392.

Klusmeyer, T. H., R. D. McCarthy, Jr., J. H. Clark, and D. R. Nelson. 1990. Effects of source and amount of protein on ruminal fermentation and passage of nutrients to the small intestine of lactating cows. J. Dairy Sci. 73:3526-3537.

Littell, R. C., G. A. Milliken, W. W. Stroup, and R. D. Wolfinger. 1996. SAS System for Mixed Models. SAS Inst., Inc., Cary, NC.

Makkar, H. P. S., and K. Becker. 1999. Purine quantification in digesta from ruminants by spectrophotometric and HPLC methods. Br. J. Nutr. 81:107-112.

Mason, V. C., S. Bech-Andersen, and M. Rudemo. 1979. Hydrolysate preparation for amino-acid determinations in feed constituents. 1. Stability of bound amino-acids to oxidation with performic acid hydrogen peroxide reagents. Z. Tierphysiologie Tierernaehrung Futtermittelkunde 41:226-235.

Mass, R. A., G. P. Lardy, R. J. Grant, and T. J. Klopfenstein. 1999. In situ neutral detergent insoluble nitrogen as a method for measuring forage protein degradability. J. Anim. Sci. 77:1565-1571.

Muck, R. E. 1987. Dry matter level effects on alfalfa silage quality. 1. Nitrogen transformations. Trans. ASAE 30:7-14.

NRC. 2001. Nutrient Requirements of Dairy Cattle, Seventh Revised Edition. National Research Council, National Academy Press, Washington, DC.

Obispo, N. E., and B. A. Dehority. 1999. Feasibility of using total purines as a marker for ruminal bacteria. J. Anim. Sci. 77:3084-3095.

Perez, J. F., C. A. Rodriguez, J. Gonzalez, J. Bacells, and J. A. Guada. 1996. Contribution of dietary purine bases to duodenal digesta in sheep. In situ studies of purine degradability corrected for microbial contamination. Anim. Feed Sci. Technol. 62:251-262.

Reynal, S. M., and G. A. Broderick. 2003. Effects of feeding dairy cows protein supplements of varying ruminal degradability. J. Dairy Sci. 86:835-843.
Robinson, P. H., J. G. Fadel, and M. Ivan. 1996. Critical evaluation of diaminopimelic acid and ribonucleic acid as markers to estimate rumen pools and duodenal flows of bacterial and protozoal nitrogen. Can. J. Anim. Sci. 76:587-597.

Santos, F. A. P., J. E. P. Santos, C. B. Theurer, and J. T. Huber. 1998. Effects of rumen-undegradable protein on dairy cow performance: A 12-year literature review. J. Dairy Sci. 81:3182-3213.

SAS. 1999-2000. SAS/STAT User's Guide (Release 8.1), SAS Inst., Inc., Cary, NC.

Satter, L. D. 1986. Protein supply from undegraded dietary protein. J. Dairy Sci. 69:2734-2749.

Shabi, Z., H. Tagari, M. R. Murphy, I. Bruckental, S. J. Mabjeesh, S. Zamwel, K. Celik, and A. Arieli. 2000. Partitioning of amino acids flowing to the abomasums into feed, bacterial, protozoal and endogenous fractions. J. Dairy Sci. 83:2326-2334.

Siddons, R. C., J. Paradine, D. E. Beever and P. R. Cornell. 1985. Ytterbium acetate as a particulate-phase digesta-flow marker. Br. J. Nutr. 54:509-519.

Sniffen, C. J., J. D. O'Connor, P. J. van Soest, D. G. Fox, and J. B. Russell. 1992. A net carbohydrate and protein system for evaluating cattle diets. II. Carbohydrate and protein availability. J. Anim. Sci. 70:3562-3577.

Uden, P., P. E. Colucci, and P. J. van Soest. 1980. Investigation of chromium, cerium and cobalt as markers in digesta. Rate of passage studies. J. Sci. Food and Agric. 31:625-632.

Ushida, K., B. Lassalas, and J. P. Jouany. 1985. Determination of assay parameters for RNA analysis in bacterial and duodenal samples by spectrophotometry. Influence of sample treatment and preservation. Reprod. Nutr. Develop. 25:1037-1046.

Volden, H., and O. M. Harstad. 1998. Amino acid composition of bacteria harvested from the rumen of dairy cows fed three diets differing in protein content and rumen protein degradability at two levels of intake. Acta Agric. Scand., Section A, Animal Sci., 48:210-215.

Volden, H., L. T. Mydland, and O. M. Harstad. 1999. Chemical composition of protozoal and bacterial fractions isolated from ruminal contents of dairy cows fed diets differing in nitrogen supplementations. Acta Agric. Scand., Section A, Animal Sci., 49:235-244.

Zinn, R. A., and F. N. Owens. 1986. A rapid procedure for purine measurement and its use for estimating net ruminal protein synthesis. Can. J. Anim. Sci. 66:157-166. 